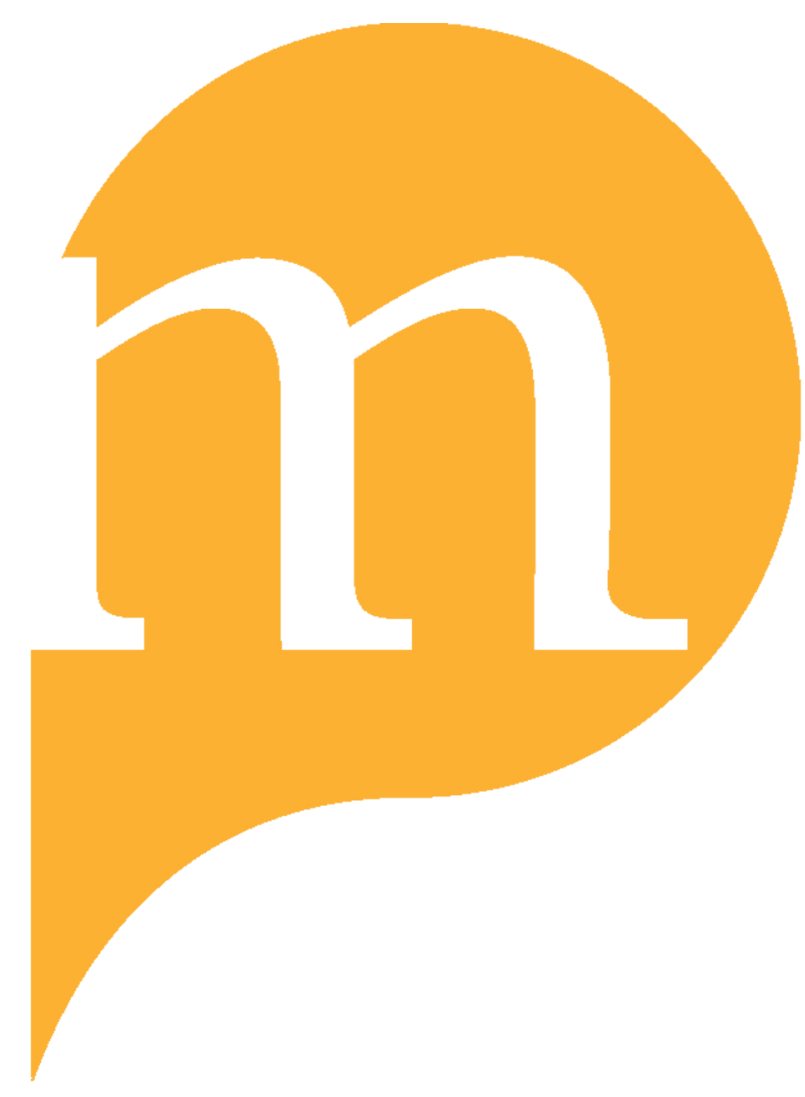

PROJECT MUSE 
Cluster on Multidisciplinary Approaches

to Teaching Dante's Commedia

\section{Teaching the Divine Comedy's Understanding of Philosophy}

fason Aleksander

The intensity of debates in the secondary literature about what "philosophy" might have meant to the author of the Divine Comedy (especially in light of its palinodic references to Dante's Convivio) suggests that the question may be insoluble. ${ }^{1}$ Still, because the question is implicated in Dante's representations of both philosophers and theologians (including a great number of speakers in Paradiso), it is bound up with many of the text's most important concerns. In fact, it is worth keeping in mind that students will first encounter the question of the Divine Comedy's understanding of philosophy very early in the text, certainly no later than in the representations of those who inhabit the portion of Limbo usually interpreted as Dante's depiction of the Elysian Fields. In its narrative voice, the Divine Comedy reports that these souls, with slow, grave eyes and great authority in their countenances, speak seldom and with soft voices (Inferno IV, 112-14); among them, Dante depicts Aristotle as enthroned, as it were, "among a philosophical company" in which "all gaze at him, all do him honor" (IV, 132-33).

First-time readers of the Divine Comedy frequently seem tempted to read Inferno IV as identifying philosophy with a particular kind of spiritual failure, probably because they tend to harbor a superficial understanding of medieval conceptions of the relationship between faith and reason. This understanding is also perhaps abetted by allegorical readings of the Comedy that explicitly associate Virgil with reason and so interpret Virgil's fate as testimony for Dante's own supposed indictment of reason's significance in human affairs. In any case, the text tells us only that souls in Limbo are damned because of a lack of faith or signs of proper adoration of God (Inferno

Pedagogy: Critical Approaches to Teaching Literature, Language, Composition, and Culture Volume 13, Number 1 DoI 10.1215/15314200-1814188 $\quad$ (C) 2012 by Duke University Press 
IV, 34-42). Thus, it is helpful to suggest to those who hastily indict philosophy at this early point in the journey that the pilgrim will encounter other souls - souls of the elect - who exemplify virtues that Dante may intend to associate with the authority of philosophy.

Still, the assumption that Inferno IV condemns philosophy, false though it may be, harbors a reasonable intuition about the poem's distinction between the respective authoritativeness of theology and philosophy. While medieval European thinkers tended to insist on the overlapping concerns of philosophy and theology, appreciating the Divine Comedy's understanding of philosophy requires attending to the ways in which the poem demarcates these two fields. These differences are, of course, rooted in these disciplines' respective attitudes toward the legitimacy of faith as a form of knowledge about possibilities for human happiness. Consequently, teaching the Divine Comedy's understanding of philosophy depends upon the extent to which a professor is willing to take up the topic of Dante's understanding of the relationship between faith and reason.

Paradiso provides the most significant passages that relate to this topic. Of particular importance is Peter's examination of the pilgrim's understanding of the nature of faith in Canto XXIV. In his initial response to Peter's request for a definition of faith, the pilgrim refers directly to the one given in Hebrews 11.1: "Faith is the substance (sustanza) of things hoped for and argument (argomento) ${ }^{2}$ of those that do not appear, and this seems to me its quiddity" (XXIV, 64-66). But in the discussion that follows, the pilgrim offers a perspective that is reminiscent of, for instance, Thomas Aquinas's discussions of this definition in De veritate (q14 a2) and Summa theologica (II-II q4 a1). Significantly, the pilgrim seems to assert that faith and reason are complementary rather than antagonistic: "I believe in one God, sole and eternal, who moves all the heavens, unmoved, with love and desire, and for this belief I have not only proofs physical and metaphysical, but that provided me by the truth that rains down from here through Moses, through prophets, and through psalms, through the Gospel and through all of you, who wrote when the burning Spirit made you nourishers" (XXIV, 130-38). Similarly, in Paradiso XXVI, when John the Apostle asks what authority compelled the pilgrim's will to aim at the Good, the pilgrim's response appears to reiterate Canto XXIV's earlier indications that reason is indeed involved in the cultivation of the theological virtues (in this case charity): "By philosophical arguments (argomenti) and by authority descending from here, that love is necessarily imprinted on me" (XXVI, 25-27). On the other hand, even though reason - and specifically philosophical argomenti-is involved in 
the cultivation of the theological virtues, it is true that for Dante faith is the root of the theological virtues since only it can supply the requisite knowledge concerning an end that is beyond the grasp of reason. ${ }^{3}$

The issue of the relationship between reason and the theological virtues is but one way of approaching the question of Dante's understanding of the significance of philosophical activity. Philosophy, according to the tradition of its own self-understanding, does not depend upon faith for premises in its arguments. But because Dante likely accepted the commonplace medieval doctrine that truth cannot contradict truth, the Divine Comedy likely expresses the notion that, even without relying on principles supplied by revelation, philosophy's conclusions enjoy an important and legitimate authority in guiding human action. That is, because the created world at every point manifests the will of its divine author, philosophical reasoning would be a legitimate mode of human discourse insofar as it orients human beings to the felicities that are most proper to the species. Thus, whereas natural reason alone is not a sufficient condition for salvation, it may nevertheless be a necessary condition since it is involved in the cultivation of the ethical, intellectual, and theological virtues.

To help students appreciate the Divine Comedy's assessment of the significance of philosophy in this regard, I think it is necessary to encourage them to tackle another challenging issue. Since the question of human happiness is tied to Dante's understanding of the hierarchy of human virtues, it behooves the teacher to draw students' attention to the Divine Comedy's treatment of the activity that Aristotle associated with sophia, the virtue he praised as most important in human happiness. Whereas Aristotle is explicit that contemplation is the most complete and self-sufficient of human activities (Nichomachean Ethics 6.7 and 10.7-8), the Divine Comedy seems to challenge this understanding in a number of ways. An interesting example of this might be seen in Dante's representation of Belacqua in Purgatorio IV, a scene students relish for its humor. Here Dante represents Belacqua as inhabiting one of the lowest terraces of Mount Purgatory, where, rather than making the effort to strive for ethical purification, he sits, perhaps contemplating the sun by pondering shadows (his head is turned down rather than up), in the coolness of the shade (see esp. IV, 109-26). ${ }^{4}$

Moments such as the representation of the inert Belacqua or Cato's rebuke of Casella's sweet singing (see Purgatorio II, 112-33) can be understood as chastising misdirected philosophical contemplation as a kind of moral negligence. But Dante's perspective may challenge not only traditional understandings of philosophy's authority with respect to its investigation of 
metaphysical questions but also the grounds of theology's authority in that Dante perhaps suggests that even theological speculation may be of negligible practical value to the cultivation of whatever beatitudes are possible for human beings. An obvious example occurs in Beatrice's reference to St. Gregory's having learned of his errors concerning the order of angels and laughing at himself for them (Paradiso XXVIII, 133-35). Moreover, since these examples may suggest that erring on a matter of theological speculation is not necessarily a sin, they also pose a question for students about the nature of the Divine Comedy's own authority as a theological text. That is, if the Divine Comedy suggests that the veracity of theological claims is to some extent irrelevant to the question of the cultivation of virtue (and hence also to the question of salvation and damnation), then how are we to read a text that is so deliberately framed for us by its own explicitly theological perspective? This kind of question is, of course, very much of the kind that is involved in serious Dante scholarship, ${ }^{5}$ but it is always a pleasure to see students take it up with enthusiasm in the classroom.

Ultimately, however, I believe that Dante's attitude toward the limits of human reason (whether related to metaphysical or theological concerns) is best summarized in one of Virgil's more tragically inflected statements:

He is mad who hopes that our reason can traverse the infinite way taken by one Substance in three Persons. Be content, human people, with the quia; for if you had been able to see everything, there was no need for Mary to give birth; and you have seen those yearning fruitlessly whose desire would be stilled, which is given them eternally for their grief: I speak of Aristotle and Plato and many other"; and here he bent his brow and said no more, and remained troubled. (Purgatorio III, 34-45)

It is my belief that Virgil's troubled silence here is tragic because of what it reveals about him (not because of what it allegorically reveals about human reason) - because his fate is here disclosed as the ultimate expression of his character. But whether or not my readers (or my students) share my interpretation of this passage, the passage offers several points worth attending to for teachers of the Divine Comedy. First, it provides an occasion to ponder the narrative reasons for or the allegorical justice of Virgil's damnation. ${ }^{6}$ By extension, this statement challenges students to consider the extent to which the damnation of non-Christian philosophers compels any kind of conclusion about the nature of philosophy itself. Put differently, Virgil's tragic selfknowledge challenges students to understand that although (as I have pointed out above) theological and philosophical speculation may seem to stand on 
equal footing with regard to their earthly fruits, they remain on unequal footing with respect to their fundamental orientation vis-à-vis the cultivation of the theological virtues. Whereas philosophy conspicuously rejects the guidance of faith on metaphysical questions, theology embraces it. This does not in itself make theology a more pertinent guide to moral conduct, but it does mean that the theologian will tend to stand on better ground insofar as his or her own speculations will already have been oriented by a virtue that is pertinent to the possibility of salvation.

This point also raises the question of the Divine Comedy's treatment of the relationship between the active and the contemplative life. On the one hand, as discussed above, Dante seems to depict contemplative activity as, at best, irrelevant to the question of salvation and, at worst, a possible cause of moral failure. On the other hand, Dante also depicts the souls in heaven in ways that associate the contemplative life with the highest human beatitude. These depictions might seem to contradict the point concerning Dante's devaluation of the practical significance of contemplation. However, Dante's view in this regard may not be so different from that of St. Thomas, who writes of the virtue associated with contemplative activity that it is highest in an absolute sense but not with respect to the production of the very conditions that make it possible. Indeed, because Dante's own perspective on the relationship between the active life and the contemplative life can seem confusing to students, I have found it helpful to provide at least a thumbnail sketch of relevant passages of Thomas's Summa theologica (especially I-II q55-67 or, even more succinctly, II-II q179-82) or Aristotle's Nicomachean Ethics 10.7-8 along with the relevant sections of Thomas's Commentary on it.

Irrespective of the extent to which Dante's view accords with Thomas's, it does seem clear throughout the Divine Comedy that philosophy has little to recommend it in terms of its traditional claims to authoritativeness vis-à-vis its metaphysical preoccupations. On the other hand, it is also possible, I think, to make the case that the Divine Comedy reveres philosophy as the highest of earthly authorities insofar as it limits its scope to the issues most proper to it. This raises the last issue concerning which I think it is worth calling attention to the Divine Comedy's understanding of the nature and value of philosophical activity. To get at this issue, I think it is worth beginning with a hint that is provided in Convivio, where Dante discusses the necessity of a unification of philosophical and political authority:

[Aristotle's] authority is not opposed to the imperial authority; but the latter authority without the former creates a danger, and the former authority without 
the latter creates a weakness, not inherently, but as a result of the lack of harmony among the people. When the one is united with the other they are of the greatest utility and possess the most complete power. Therefore it is written in the book of Wisdom, "Love the light of wisdom, all you who are before the people," which is to say, "Let the philosophic be united with the imperial authority, for good and perfect government." (4.6.17-18)

Dante's point here is that the practical moral guidance of philosophy is crucial for establishing just rule. However, in this passage, he also depicts philosophy - embodied by Aristotle most of all - as unable to produce virtue without the assistance of the laws.

There are two cantos in the Divine Comedy in which this view receives special consideration. The first is Purgatorio XVI, where Marco offers the following diagnosis of the cause of civil strife in the Italy of Dante's day: "Rome, which made the good world, used to have two suns that made visible the two paths, of the world and of God. One sun has extinguished the other, and the sword is joined to the shepherd's staff, and it is ill for those two to be violently forced together, for, joined, neither fears the other" "(106-12). Marco's speech here reveals a political philosophy that is articulated explicitly and in greater detail in both Convivio and Monarchia, but the conclusion is obvious anyway: for Dante, good governance, provided only by a universal monarch whose authority is inviolable, is in fact the very thing that makes it possible for the spiritual authority of the Church to guide human beings effectively. Specifically, this universal secular authority provides the civil peace necessary for the cultivation of ethical virtue as well as the conditions under which citizens might best attend to their spiritual needs. Accordingly, where Marco asserts in Purgatorio (XVI, 91-96) that either a guide or reins would be necessary to turn human appetite away from base pleasures so that the human being may be genuinely happy, the extrinsic "reins" would be the laws, whereas the intrinsic "guide" would be philosophy as ethics.

Students find this canto to be a helpful access to Dante's political philosophy, and it is worth attending to for this reason alone. However, even while it roughly concurs with the political philosophy articulated in both Monarchia and Convivio, it does not explicitly refer to the political significance of philosophy, and I would suggest attending to Dante's arguments in these other sources. But for the intrepid student who wishes to pursue the topic in Divine Comedy, Thomas's discussion of Solomon's "regal prudence" in Paradiso XIII provides an important confirmation since Solomon is there depicted as having bound together both the force of law and the moral insight 
of philosophy - not because he asked for the wisdom associated with contemplative activity, but because he requested the kind of wisdom that would be useful for a king:

"I have not spoken in such a way that you cannot see clearly that he was a king who asked for the wisdom to be a worthy king, not in order to know the number of the Movers up here, or if necesse with contingent ever made necesse, not si est dare primum motum esse, or whether in a semicircle one can make a triangle that lacks a right angle. Thus, if you consider this and what I have said, the prudence of a king is that unequaled seeing at which the arrow of my intention strikes." (94-105)

This characterization of Solomon tells us that, for Dante, wisdom is refigured as being esteemed for its practical value rather than its value in a contemplative life. In refiguring wisdom in this way, Dante, I believe, associates philosophy most of all with the virtue of prudence - the virtue Aristotle called phronesis and discusses at length in Nicomachean Ethics $(6.8-13){ }^{7}$

To conclude, let me recapitulate the five main topoi through which I believe students might be encouraged to explore the question of the Divine Comedy's understanding of philosophy. These topoi involve the Divine Com$e d y$ 's concerns with (1) the infernal status of noble pagans who are allegorically or historically associated with philosophy or natural reason, (2) the relationship between faith and reason and its consequences for the text's understanding of the respective authoritativeness of theology and philosophy, (3) the practical value of philosophical (not to mention theological) speculation, (4) the respective merits of practical and contemplative activities, and (5) philosophy's authority with respect to ethical and political questions. This fifth topic - the Divine Comedy's concerns with philosophy's practical authority - deserves a final additional comment. If I am right that the question of the Divine Comedy's understanding of philosophy is intimately bound up with the text's construction of its authoritative voice in matters of ethics and politics, then it is also true that helping students question and discuss the text's assertion of its relevance to the lives of its readers should entail active encouragement that they consider the poem's understanding of and appeal to philosophy's authority. 


\section{Notes}

1. Significant scholarly discussions of the Divine Comedy's understanding of philosophy can be found in Foster 1965, Gilson ([1949] 1963), and Stone 2006. Significant scholarly discussions of the import of the Divine Comedy's palinodic references to the Convivio include Freccero 1973; Hollander 1975, 1990; Pertile 1993; Scott 1990, 1991, 1995; and Ascoli 1995 .

2. Most English versions of the Vulgate translate the Latin "argumentum" in Hebrews 11.1 with "evidence." Similarly, most translators render Dante's "argomento" in Paradiso XXIV with "evidence." This is a teachable moment, and it reinforces the point I have made above concerning the value of providing students with some background on medieval philosophy and theology. Thomas Aquinas, for instance, explicitly discusses four main meanings of "argumentum" in De veritate (q14 a2 ad9), and only one of these possible meanings corresponds directly with "evidence." Consequently, it is worth calling students' attention to the varied senses Dante may have been drawing upon in this canto.

3. It may be helpful to discuss with students what "knowledge" (scientia) might mean in this context. At the beginning of the Summa theologica, for instance, Thomas Aquinas distinguishes between scientiae that are rooted in natural reason and the peculiar kind of scientia that theology involves (see especially I q1 a2).

4. Belacqua is generally regarded as a musician that Dante had known in Florence. Nonetheless, his representation in Purgatorio IV seems to me to suggest a contemplative rather than musical posture.

5. To mention but two recent examples, Barolini 1992 specifically discusses the formal significance of theology to the poem's narrative framework, and Ascoli 2008 discusses Dante's general strategies for attempting to establish his own poetic auctoritas.

6. An accessible introduction to discussions of the narrative logic and/or theological doctrine in the representation of Virgil may be found in the exchange between Mowbray Allan and Teodolinda Barolini (Allan 1989, 1990; Barolini 1990a, 199ob). In relation to the question of the Divine Comedy's understanding of philosophy, other significant discussions of Virgil include Barolini 1984, 201 - 69; Foster 1977, 156-253; and Singleton 1956.

7. For a fuller articulation of this argument, see Aleksander 2011. Other discussions of Dante's representation of Solomon's wisdom in the Heaven of the Sun include Kirkpatrick 1978, Simpson 1989, Mazzotta 2003, and Williams 2005.

\section{Works Cited}

Aleksander, Jason. 2011. "Dante's Understanding of the Two Ends of Human Desire and the Relationship between Philosophy and Theology." Journal of Religion 91: 158-87.

Alighieri, Dante. 1990. Convivio, trans. Richard Lansing. New York: Garland.

__ 1997-2010. The Divine Comedy, trans. Robert M. Durling. 3 vols. Oxford: Oxford University Press.

Allan, Mowbray. 1989. "Does Dante Hope for Virgil's Salvation?" MLN: Modern Language Notes 104: 193-205.

\section{Pedagogy}


___ 1990. "Response to Teodolinda Barolini." MLN: Modern Language Notes 105:

$144-47$.

Ascoli, Albert Russell. 1995. "Palinode and History in the Oeuvre of Dante." In Dante Now:

Current Trends in Dante Studies, ed. Theodore J. Cachey, 115-86. Notre Dame, IN:

University of Notre Dame Press.

—_ 2008. Dante and the Making of a Modern Author. Cambridge: Cambridge University

Press.

Barolini, Teodolinda. 1984. Dante's Poets: Textuality and Truth in the Comedy. Princeton,

NJ: Princeton University Press.

___ 1990a. "Q: Does Dante Hope for Vergil's Salvation? A: Why Do We Care? For the

Very Reason We Should Not Ask the Question (Response to Mowbray Allan)." MLN:

Modern Language Notes 105: 138 - 44 .

___ 199ob. "Second Response to Mowbray Allan." MLN: Modern Language Notes 105:

$147-49$.

—_- 1992. The Undivine Comedy: Detheologizing Dante. Princeton, NJ: Princeton

University Press.

Foster, Kenlem. 1965. "Religion and Philosophy in Dante." In The Mind of Dante, ed.

Uberto Limentani, 47-78. Cambridge: Cambridge University Press.

___ 1977. The Two Dantes, and Other Studies. Berkeley: University of California Press.

Freccero, John. 1973. "Casella's Song (Purg. II, 112)." Dante Studies 91: 73-80.

Gilson, Étienne. (1949) 1963. Dante and Philosophy, trans. David Moore. New York:

Harper and Row.

Hollander, Robert. 1975. "Purgatorio II: Cato's Rebuke and Dante's scoglio." Italica 52: $348-63$.

—_ 1990. "Purgatorio II: The New Song and the Old." Lectura Dantis 6: 28-45.

Kirkpatrick, Robin. 1978. Dante's Paradiso and the Limitations of Modern Criticism:

A Study of Style and Poetic Theory. Cambridge: Cambridge University Press.

Mazzotta, Giuseppe. 2003. "The Heaven of the Sun: Dante between Aquinas and

Bonaventure." In Dante for the New Millennium, ed. Teodolinda Barolini and

H. Wayne Storey, 152-68. New York: Fordham University Press.

Pertile, Lino. 1993. "Dante's Comedy beyond the Stilnovo." Lectura Dantis 13: 47-77.

Scott, John. 1990. "Dante and Philosophy." Annali d'Italianistica 8: 258-77.

- 1991. "Beatrice's Reproaches in Eden: Which 'School' Had Dante Followed?"

Dante Studies 109: 1-23.

___ 1995. "The Unfinished Convivio as Pathway to the Comedy." Dante Studies 113:

$31-56$.

Simpson, James. 1989. "Poetry as Knowledge: Dante's Paradiso XIII." Forum for Modern Language Studies 25: 329-43.

Singleton, Charles. 1956. "Virgil Recognizes Beatrice." Dante Studies 74: 29-38.

Stone, Gregory. 2006. Dante's Pluralism and the Islamic Philosophy of Religion. New York: Palgrave Macmillan.

Williams, Pamela. 2005. "Dante's Heaven of the Sun and the Wisdom of Solomon."

Italica 82: 165-79. 


\section{For Further Reading}

Foster, Kenlem. 1965. "Religion and Philosophy in Dante." In The Mind of Dante, ed. Uberto Limentani, 47-78. Cambridge: Cambridge University Press. Argues that Dante assigns philosophy an important but subordinate role to theology in human activity.

Gilson, Étienne. (1949) 1963. Dante and Philosophy, trans. David Moore. New York: Harper and Row. Originally published in 1939 in French. Often considered the locus classicus for contemporary discussions of the issue, Gilson famously argues that Dante conceives philosophy's authority as independently grounded and central to ethical and political thinking.

Stone, Gregory. 2006. Dante's Pluralism and the Islamic Philosophy of Religion. New York: Palgrave Macmillan. Argues that Dante's conception of philosophy and its relationship to revelation resembles the philosophies of religion of al-Farabi and Averroes. 